\title{
Environmental Consequences of Long-Term Development of Petroleum Fields, Absheron p-la, Azerbaijan, Case History
}

\author{
Akper A. Feyzullayev, Vagif B. Ibragimov \\ Geology Institute of Azerbaijan National Academy of Sciences, Baku, Azerbaijan \\ Email: afeyzullaev@gia.ab.az
}

Received 28 September 2014; revised 23 October 2014; accepted 15 November 2014

Copyright (C) 2014 by authors and Scientific Research Publishing Inc.

This work is licensed under the Creative Commons Attribution International License (CC BY). http://creativecommons.org/licenses/by/4.0/

(c) (i) Open Access

\begin{abstract}
In this paper the overview of a level of study of the deformation processes on long-term petroleum field development and ecological consequences accompanying them is given. In more details these processes are considered for the oldest Absheron petroleum bearing region (Absheron p-la, Azerbaijan) where fields are strongly depleted and the pressure drop reaches $80 \%$ from initial values. Ecological consequences of this phenomenon are the following: development in area of petroleum fields Balakhany-Sabunchi-Ramany, Surakhany, Garachukhur, Bibi-Eybat intensive process of ground subsiding (up to $47 \mathrm{~mm} /$ year) and flooding, frequent incidences of curved boreholes, breaks in oil, gas, and water pipelines, and sudden kicks of water and sand, occurrence of the induced seismicity (Surakhany earthquake in 1937 with magnitude 6). With purpose of forecasting of geodynamic processes creation on petroleum production complexes of system of the environmental control is recommended.
\end{abstract}

\section{Keywords}

Petroleum Field, Development, Ground Subsiding, Flooding, Induced Seismicity, Absheron p-la, Azerbaijan

\section{Introduction}

As is known large amounts of oil, gas and associate water are extracted from the subsoil when carrying out long term hydrocarbon field development. This results in the significant pressure decline in the reservoirs which, according to different estimates, is $50 \%$ - $80 \%$ below hydrostatic pressure [1]. Such pressures are classified as abnormally low reservoir pressures (ALRP) [2]. 
The reservoir pressure decline leads to the increase of the effective pressure which in its turn causes deformation processes such as decrease of rock porosity and permeability as well as additional compaction [3]. This process finds its reflection in the change of the environmental situation in the oil fields which is manifested in the soil subsidence [4] [5], under flooding [6], appearance of "induced" seismicity [7]; that finally can cause damages for the infrastructure (well, platform and pipeline failure and others) and require large investments for its rehabilitation [8].

In this paper an overview of the problem study in the world and analysis of some of its aspects for the Absheron peninsula (Azerbaijan) (Figure 1), where oil and gas fields have been developed for more than a century and are currently considerably depleted, is provided.

\section{Overview of Problem}

\subsection{Land Subsidence and Flooding}

There are distinguished three types of manmade extraction of subsoil fluids which under favorable geological conditions can cause significant LS: 1) oil, gas and associated water production; 2) hot water or steam extraction for the purpose of using geothermal energy 3) ground water extraction. Each of them causes maximal LS nearly of the same order of magnitude. Thus, for instance, the LS at the well known Wilmington oil field (California State, USA) reached 9 meters. Hot water extraction for the purpose of using geothermal energy in Wairakei (New Zealand) led to 6 - 7 meters of subsidence, and ground water extraction in Mexico (Mexico) and in San Joaquin valley in California (USA) caused the 9 meter LS [9].

Land subsidence connected with intensive hydrocarbons production is observed in many regions of the world. Such phenomenon was for the first time recorded in 1926 at the Goose Creek oil field not far from Houston (Texas State, USA). Here the oil production from loose sandstones and silts from the depth of 350 - $1400 \mathrm{~m}$ (thickness of the oil bearing interval more than $300 \mathrm{~m}$ ) during the period of 1917-1925 led to $1 \mathrm{~m}$ subsidence [10]-[12]. Later, the similar effect was identified at other areas. Particularly, the rate of changeable in space and

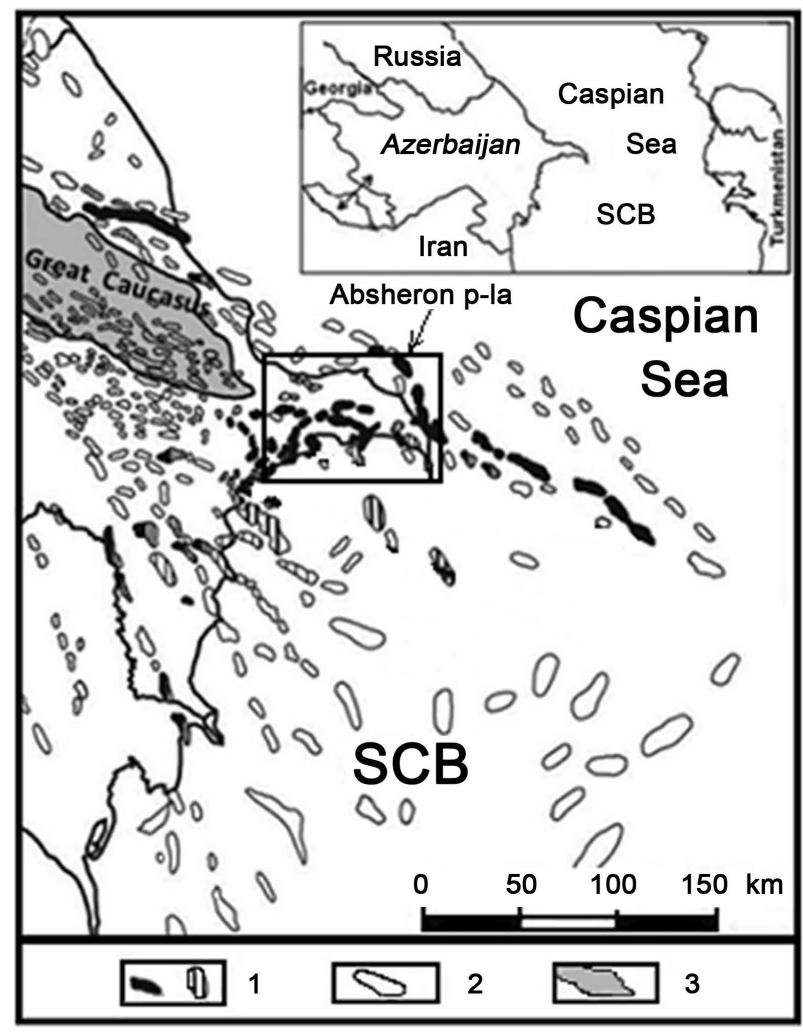

Figure 1. Location of Absheron p-la, Azerbaijan. 1: petroleum fields; 2: structures; 3: mountains. 
time LS at Belridge and Lost Hills oil fields in California (USA) reaches 30 - $40 \mathrm{~cm}$ annually [13]. In HoustonGalveston (Texas area, USA), where there are at least 110 oil and gas fields, 29 fields have been crossed by the lines of relevelling. Six of them have been discovered to have local land subsidence: Alco-Mag, Chocolate Bayou, Goose Creek, Hastings, Mykawa and South Houston, whereas the LS rates (up to $120 \mathrm{~mm} /$ year) exceeded the natural subsidence rates estimated to be $13 \mathrm{~mm} /$ year [12]. It is thought that such rapid LS rates have been caused by the large scale removal of fluids forming a large subsidence cup [14].

This phenomenon is thought to have two main reasons: a) natural, related with geological process of sediments compaction, and b) manmade ones. The first ones though widely spread are characterized by relatively low rate of LS compared with the second ones. For instance, the study of the history of development and reservoir pressure at some large oil and gas fields in Louisiana state (USA) suggested that the rates of the man-induced LS reach $9 \mathrm{~mm} /$ year or $23 \mathrm{~mm} /$ year (depending on whether these data have been obtained based on the results of releveling or sea level records), whereas geological rates of LS come up to about $3 \mathrm{~mm} / \mathrm{year}$ [4] [15]. The rates of LS at the Port Neches field in Texas (USA) in the period of maximal petroleum production and discovered that the computed rate of land subsidence (30 mm/year) are 3 order higher than the geological rates of LS at the coastal valley [15]. The average historical rate of LS in the Mississippi delta is $12 \mathrm{~mm} /$ year [16] which is higher than the average geological rates of LS [17].

Considerable LS at the developed hydrocarbon pools is observed under the presence of all or some of the following conditions: 1) essential drop of the reservoir pressure during the hydrocarbons production [22]; 2) hydrocarbons production from wide depth interval [18]; 3) oil or gas (separately or together) are contained in slightly consolidated or slightly cemented rocks; 4) reservoirs have a relatively shallow depth occurrence and considerable extension.

Collection, classification and analysis of the published data on more than 130 hydrocarbons pools under production have discovered the LS occurrence from tens of centimeters to several meters [19] [20]. Special studies have established the following characteristic features of the considered phenomenon:

-The rapid decline of the hydrocarbons production leads to the reduction of LS rates. So, as a rule, the initial intensive period of the field development is characterized by higher LS rates which later slow down whereas in some cases subsidence stops.

-LS on the developed oil and gas fields has usually local character. However, hydrocarbon production from one bed on several relatively near fields can lead to the regional pressure loss and regional LS [21].

-LS can be restrained by means of reservoir pressure recovery/maintenance. At the same time, the process of recovery can be successful if only all fault blocks work as a whole. According to some researchers actions aimed at maintaining the reservoir pressure by means of water injection into the bed and other methods applied at many fields worldwide allow to recovery pressure not exceeding $10 \%$ of initial value. It is connected with the fact that inelastic deformations of rocks accompanying the reservoir pressure decline are more significant than the elastic ones which leads to irreversible process of reservoir rocks consolidation [3]. Therefore restore the reservoir pressure to the initial value will not lead to the recovery of the initial reservoir capacity [22].

Widely spread processes of reservoir compaction and subsidence belong to the categories of dangerous natural phenomena which are inevitably accompanied by serious environmental and economic consequences. The economic consequences include flooded territories due to LS especially in coastal areas where even slight LS can cause flooding. Such phenomenon was for the first time described for the oil field near Houston (Texas State, USA). The land subsidence which reached almost 9 meters due to the oil extraction from the main Wilmington field [9] led to the flooding of streets and piers in the city and in the Long Beach port (California, USA), caused damages to the bridges, railways and other port facilities [23]. The smaller LS ( 1 m) at the Goose Creek field (Texas, USA) was enough to change the landscape from the green highland to open water. LS in Venezuela led to the huge flood at the coastal area of the Maracaibo Lake, and in Russia large oil bearing areas in Western Siberia turned into swamps due to similar reasons [6].

Economic consequences of LS as the result of hydrocarbons production often cause serious damages to the existing infrastructure (well, pipeline and platform failure etc.). According to one of the present day estimates the annual damage caused by LS due to hydrocarbons production within the USA comes up to more than 100 million dollars [8]. Here should also be added the so called "postponed" damage which will be quite appreciable by future generations: it has been established that 2 - $3 \mathrm{~m}$ of LS lead to the reduction of crop yield by $10 \%, 5$ - 6 $\mathrm{m}$-by $50 \%$, and more than $8 \mathrm{~m}$ —cropland is totally destroyed [24]. 


\subsection{Induced Seismicity}

It has been established that man's activity can also provoke emergence or intensification of seismic activity in the areas of hydrocarbons production. Such seismicity was named as man caused. In literature it is often referred to as "caused", "induced", "excited", "generated" etc. With the purpose of unification of terminology Russian scientists V. V. Adushkin and S. B. Turuntaev [7] offers all seismic events which occur due to various reasons after or in the process of man caused impact to define as induced seismicity.

The occurrence and intensity of induced seismicity at developed oil and gas fields depend on the geologicaltectonic properties of the reservoir and surrounding massif, its mode of deformation, degree of blockiness and presence of heterogeneity, rates and volumes of hydrocarbons extraction and water injection [25]. According to the analysis of 200 fields situated in different regions of the world the likelihood of induced subsidence occurrence increases with the increase of depth and thickness of the developed bed as well as with the decline of reservoir porosity and permeability. Therewith, focuses of induced seismicity occur at various depths (depending on the geological structure of the massif) over and below the productive zones, and its strengthening happens in case of misbalance between the volume of extracted oil and injected liquid.

Researches show, that the interval of time between the beginning of development of petroleum fields and the provoked activization of seismic activity for gas fields is less (2 - 16 years), than for oil (7 - 39 years) [26].

The examples of induced seismicity are well known: it are disastrous earthquakes in the area of the Gazli gas field in 1976 and in 1984 with magnitudes from 6.8 to 7.3, and the Neftegorsk earthquake in 1995 with the magnitude of 7.2 - 7.6 which was the consequence of the active oil production on the Sakhalin island [27].

\section{Results and Discussion}

As is known the history of oil production on the territory of the Absheron peninsula (Azerbaijan) goes back to the middle of the XIX century when oil was extracted from shallow wells dug by hand. Later with the introduction of well drilling technology the intensity of hydrocarbons extraction from reservoirs was continuously increasing and by the end of the XX century exceeded one billion tons of oil (plus the extraction of large amounts of associated gas and reservoir water). This resulted in the abrupt decline of reservoir pressures.

The analysis suggests that in operated sites of the productive stratum of the Absheron peninsula the initial reservoir pressures which approximately corresponded to hydrostatic ones dropped from 52.3\% (Gala field) to 80.6\% (Chakhnaglar-Sulutepe field). Whereas the level of primary pressure drop in the reservoirs of the upper formations of the productive stratum is higher (in average about 66\%) than in the reservoirs of the lower formations (58.9\%) of the productive stratum.

The level of present day pressures in comparison with the primary ones is shown on the diagram of their change with depth built according to the data of about 15 fields of Absheron peninsula (Figure 2).

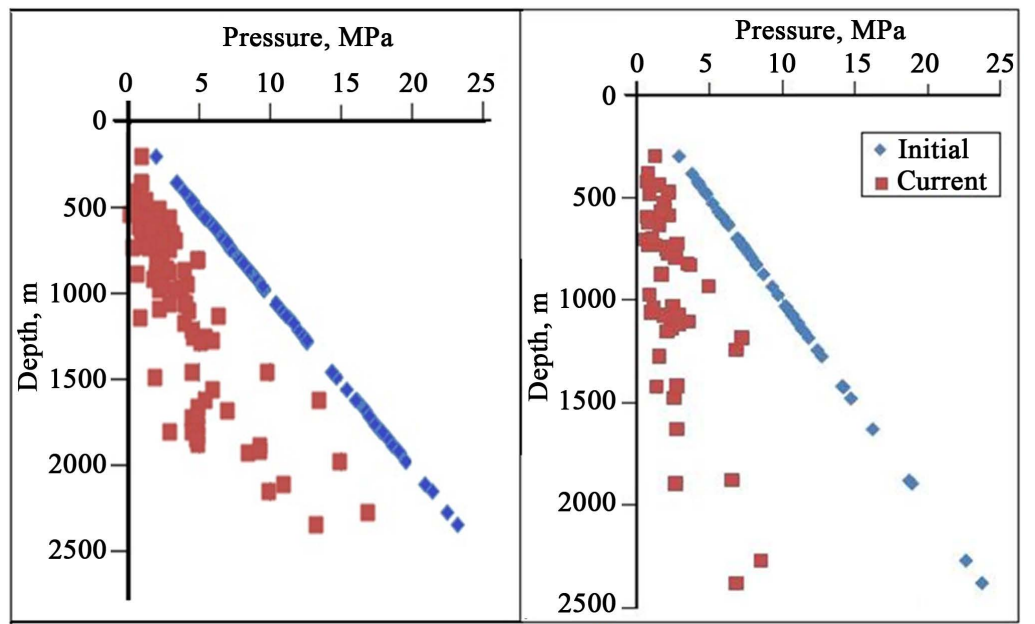

Figure 2. Change with depth of initial and current (as of 01.01.2009) reservoir pressures at the fields of Absheron peninsula (on left) and at oldest and largest Balakhany-Sabunchi-Ramany field, which placed in operation in 1873-1890. 
The development of corresponding deformation processes which can be identified by special studies for example monitoring of present day vertical movements of the earth crust must have been the natural consequence of the reservoir pressure decline in the fields of the Absheron peninsula. Such monitoring at the Absheron peninsula was launched as early as in 1912 when the geodynamic polygon being one of the first in the world was established here. The purpose of the first geodetic measurements was to identify differences in terms of altitude of the levels of the Caspian and Black seas.

While processing the relevelling data it was discovered that separate areas of the Absheron peninsula vary with altitude [28]. In particular, attention was paid to the subsidence of the central eastern parts of the peninsular (Figure 3). Later there was detected subsidence of the Bibi-Eybat oil field territory. For instance, LS with the speed of $30 \mathrm{~mm} /$ year was detected in the area of one of the oldest wells No. 2465, and in the area of the well No. 2778-31 mm/year. The similar phenomenon was observed at other fields of the peninsular (Table 1). In absolute values the presence of abnormal cases in fold areas of anticlines at the oldest oil fields in Sabunchi, Surakhany, Ramany and Bibi-Eybat reached $1-2.5 \mathrm{~m}$ for the period of 50 years, and during 80 years the central part of the Absheron peninsular subsided by more than $3 \mathrm{~m} \mathrm{[29].}$

Though the analysis of the results of relevelling carried out on the Absheron peninsula did not contribute to unanimous opinion as to the causes of LS, however, a number of scientists link one of them to the intensive extraction of oil, gas and sand from the subsoil. Thus, according to the observations of D.A. Liliyenberg and others [30] the periods of relative tectonic LS at the fields of Binagadi, Surakhany and Bibi-Eybat correspond to the sudden increase of hydrocarbons extraction from the subsoil, whereas the periods of movement stabilization or relative elevation are associated with minimal production. The diagram shown in Figure 4 illustrates the noticeable tendency for the increase of average annual rate of the vertical earth crust movements accompanied by the increase of the average annual oil production at the fields of the Absheron peninsula (without accounting of extraction of gas and associated reservoir waters).

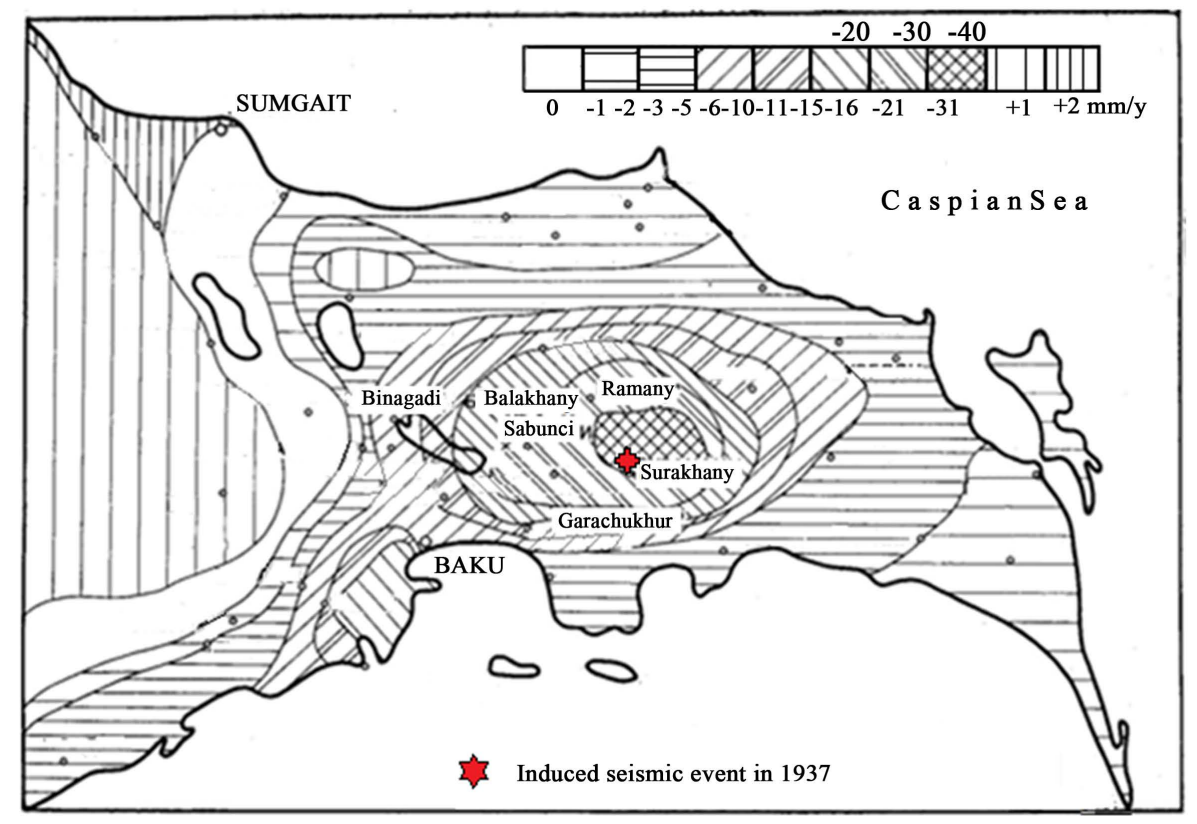

Figure 3. Scheme of vertical movements on Absheron p-la based on results repeated leveling.

Table 1. Land subsidence at some fields of the Absheron peninsular.

\begin{tabular}{cccc}
\hline Field & Years of levelling & Time interval, years & Annual average rate, mm/year \\
\hline Binagadi & $1912-1937$ & 25 & -2 \\
Bibi-Eybat & $1908-1972$ & 64 & -30 \\
Surakhany & $1926-1974$ & 48 & -30 \\
\hline
\end{tabular}


Average annual oil recovery, th.ton/year

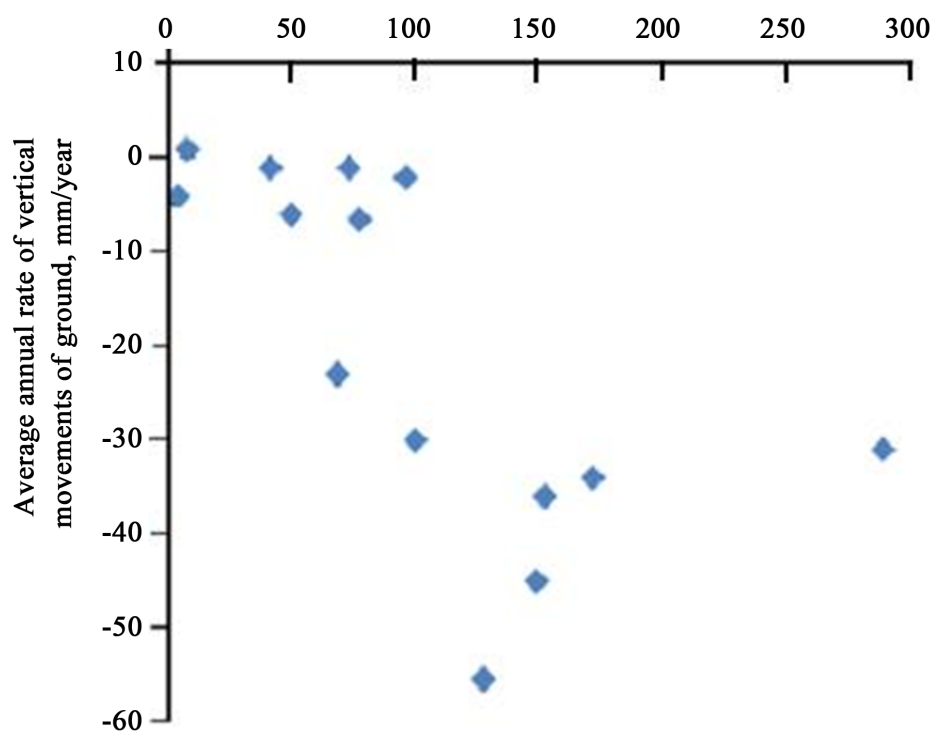

Figure 4. Diagram of dependence of earth crust movement speed on average annual oil production at the fields of Absheron peninsula (created based on Yashenko's data [28]).

The above pointed processes of land subsidence in the Absheron peninsula as well as at long term developed oil fields of other basins in the world were also accompanied by negative environmental consequences. Thus, according to the data of the hydrodynamic monitoring carried out in the Absheron peninsula there have been identified areas of intense rising of level of underground water correlating to LS areas. In particular, in the central part of the peninsular the area of zones with the depth of ground water level of $>10 \mathrm{~m}$ decreased by $21.4 \%$ during the period from 1955 to 2006, and the area of zones with the depth of ground water level of $3-5 \mathrm{~m}$ increased by $10.3 \%$. This serves as a vivid example of the negative impact of the long term development of oil and gas fields in this territory for hydrogeological and ecological environments which is manifested in flooding (in other cases-swamping) of territories and obvious deterioration of ameliorative properties of lands.

Abnormal rates of LS in the number of fields of the Absheron peninsula can serve as a cause of the man-induced seismicity. Abnormal rates of subsiding in area of Surakhany field (about $47 \mathrm{~mm} /$ year) have served as the reason for earthquake of magnitude 6 which occurred in 1937 near the same named village (see Figure 3).

Oil and gas production at the intensely developed oil fields of the Absheron peninsula was often accompanied by cases of borehole curving and breaking, oil, gas and water pipeline rupture, sudden water and sand kick etc. which were the results of man induced deformation processes combined with natural geodynamic processes. Thus, for example in the Balakhany-Sabunchi-Ramany field in more than 20 wells there were reported cases of breakage (wells No. 1794, 2304 and others) and breakage of borehole lines (wells No. 2409, 2575, 2610 and others) as well as their curving (wells No. 1499, 12204 and others) which led to serious economic damages [28].

Well failures are causing large scale contamination of oil-field territories too. Two monitoring conducted in Azerbaijan over the last years by the Ministry of Ecology and Natural Resources identified around 30 thous. ha of contaminated land of which 10 thous. ha (according to other data-12 thous. ha) fall on land contaminated with oil and oil products essentially in the Absheron peninsula.

It is known that on completing the field development oil/gas wells used for the production of hydrocarbons are abandoned or temporary suspended. However, the extent of risk of dangerous (emergency) situations will not decrease as the control over their condition is often either not exercised or exercised quite cursorily without taking into account all the requirements of relevant regulatory acts [31].

According to the independent experts (no official data-Authors) in Azerbaijan only on the territory of the Absheron peninsular there is a concentration of up to 3 thousand abandoned i.e. uncontrolled oil wells.

A more detailed analysis of these and a number of other environmental problems is the subject of separate researches. 


\section{Conclusions}

Overview of references has shown that intensive development of oil-and-gas fields causes natural disbalance and wide progress of deformation processes: decline of reservoir pressure induced additional compaction of rocks and as a result, subsidence and displacement of a ground occur.

The above mentioned undesirable environmental consequences of the long term development of oil and gas fields in the aggregate cause considerable economic damage to the existing infrastructure. For minimization of such damage it is necessary to equip petroleum producing complexes by system of environmental control with purpose of forecasting geodynamic processes development.

\section{References}

[1] Xie, X., Jiao, J.J., Tang, Z. and Zheng, C. (2003) Evolution of Abnormally Low Pressure and Its Implications for the Hydrocarbon System in the Southeast Uplift Zone of Songliao Basin, China. AAPG Bulletin, 1, 99-119.

[2] Koshlyak, V.A. (2002) Granitoid Oil and Gas Reservoirs. Tau-Press, Ufa.

[3] Imanov, A.A. (2012) Physical and Mechanical Properties Sedimentary Rocks of the South-Caspian Basin in Subsurface Conditions: Deep Water Hydrocarbons Resources. Nafta-Press, Baku.

[4] Morton, R.A. and Buster, N.A. (2002) Subsurface Controls on Historical Subsidence Rates and Associated Wetland Loss in South-Central Louisiana. Gulf Coast Association of Geological Societies, 52, 767-778.

[5] Patel, P. and Kulkarni, M.N. (2007) Application of GPS for Monitoring Land Subsidence. Journal of Earth Sciences, 1, 35-46.

[6] Serebryakov, V.A. and Chilingar, G.V. (2000) Prediction of Subsidence: Relationship between Lowering of Formation Pressure and Subsidence Due to Fluid Withdrawal. Energy Sources Part A: Recovery, Utilization and Environmental Effects, 5, 409-416.

[7] Adushkin, V.V. and Turuntaev, S.B. (2005) Man Induced Processes in the Earth Crust (Hazards and Catastrophes). INEK, Moscow.

[8] National Research Council (1991) Mitigating Losses from Land Subsidence in the United States. National Academy Press, Washington DC.

[9] Mayuga, M.N. and Allen, D.R. (1970) Subsidence in the Wilmington Oil Field, Long Beach, California, U.S.A. In: Tison, L.J., Ed., Land Subsidence, International Association of Scientific Hydrology, UNESCO, 66-79.

[10] Pratt, W.E. and Johnson, D.W. (1926) Local Subsidence of the Goose Creek Oil Field. Journal of Geology, 34, 577590. http://dx.doi.org/10.1086/623352

[11] Snider, L.C. (1927) A Suggested Explanation for the Surface Subsidence in the Goose Creek Oil and Gas Field, Texas. AAPG Bulletin, 11, 729.

[12] Holzer, T.L. (1990) Land Subsidence Caused by Withdrawal of Oil and Gas in the Gulf Coastal Plain, the Houston, Texas, Case History. AAPG Bulletin, 74, 1497-1498.

[13] Van der Kooij, M. (1997) Land Subsidence Measurements at the Belridge Oil Fields from ERS InSAR Data. The 3rd ESA ERS Symposium, Florence. http://earth.esa.int/workshops/ers97/papers/vanderkooij1/index-2.html

[14] Gabrysch, R.K. and Coplin, L.S. (1990) Land-Surface Subsidence in Houston-Galveston Region, Texas. Texas Water Development Board Report, No. 188, Austin.

[15] Morton, R.A., Purcell, N.A. and Peterson, R.L. (2001) Field Evidence of Subsidence and Faulting Induced by Hydrocarbon Production in Coastal Southeast Texas. Gulf Coast Association of Geological Societies Transactions, 51, 239248.

[16] Shinkle, K. and Dokka, R.K. (2004) Rates of Vertical Displacement at Benchmarks in the Lower Mississippi Valley and the Northern Gulf Coast. NOAA Technical Report, No. 50, 135 p.

[17] Penland, S., Ramsey, K.E., McBride, R.A., Mestayer, J.T. and Westphal, K.A. (1988) Relative Sea-Level Rise and Delta-Plain Development in the Terrebonne Parish Region. Coastal Geology Tech Report, No. 4, 121 p.

[18] Hejmanowski, R. (1993) Zur Vorausberechnung förderbedingter Bodensenkungen über Erdölund Erdgaslagerstätten (Prediction of Land Subsidence Induced by Oil and Gas Exploitation). Ph.D. Thesis, Clausthal University of Technology, Clausthal-Zellerfeld.

[19] Melnikov, N.N. and Kalashnik, A.I. (2009) Man Induced Geodynamic Processes When Developing Oil and Gas Fields of the Barents Sea Shelf. Vestnik MGTU, 12, 601-608.

[20] Nesterenko, Y.M., Kosolapov, O.V. and Nesterenko, M.Y. (2010) Seismic Activity in the Regions of the Developed Hydrocarbons Fields. News of the Samara Scientific Center of the RAS, 12, 1240-1244. 
[21] Kreitler, C.W., Akhter, M.S., Donnelly, A.C.A. and Wood, W.T. (1988) Hydrogeology of Formations Used for DeepWell Injection. Texas Gulf Coast: University of Texas at Austin Bureau of Economic Geology, Austin, 204 p. Report Prepared for the U.S. Environmental Protection Agency under Cooperative Agreement No. CR812786-01-0.

[22] Doornhof, D., Kristiansen, T.G., Nagel, N.B., Pattillo, P.D. and Sayers, C. (2006) Compaction and Subsidence. Oilfield Review, 18, 50-68.

[23] Poland, J.F. and Davis, G.H. (1969) Land Subsidence Due to Withdrawal of Fluids. Reviews in Engineering Geology, 2, 187-269. http://dx.doi.org/10.1130/REG2-p187

[24] Gorshkov, S.P. (1998) Conceptual Basics of Geoecology. Smolensk State University, Smolensk.

[25] Adushkin, V.V., Rodionov, V.N. and Turuntaev, S.B. (2000) Seismicity of Hydrocarbons Fields. Oil Review, 5, 4-15.

[26] Kononova, M. (2011) Earthquakes. Characteristic. Examples. St. Petersburg State University, St. Petersburg.

[27] Nikolaev, A.V. (1995) Problems of Induced Seismicity. In: Nikolaev, A.V. and Galkin, I.N., Eds., Induced Seismicity, Nauka, Moscow, 5-15.

[28] Yashenko, V.R. (1989) Geodesic Researches of Vertical Movements of the Earth Crust. Nedra, Moscow, 192 p.

[29] Yashenko, V.R. and Yambayev, H.K. (2006) Geodesy and Eternal Mysteries of the Earth Crust Movements. Geoprofi, 4, 61-66.

[30] Lilienberg, D.A., Guseinzadeh, O.D., Kuliyev, F.T., Shirinov, N.Sh. and Yashenko, V.R. (1980) Complex Studies of Present Day Tectonic Movements on the Geodynamic Polygons of Azerbaijan. In: Bulanzhe, Yu.D., Lilienberg, D.A. and Podstrigach, Ya.S., Eds., Present Day Movements of the Earth Crust. Theory, Methods, Forecast, Nauka, Moscow, 165-174.

[31] Muzipov, H.N., Yerka, B.A. and Illarionova, E.G. (2009) Environmental Safety of Plants of the Exploration and Production Sector. Neftyanoe Khozaystvo, 1, 92-94. 
Scientific Research Publishing (SCIRP) is one of the largest Open Access journal publishers. It is currently publishing more than 200 open access, online, peer-reviewed journals covering a wide range of academic disciplines. SCIRP serves the worldwide academic communities and contributes to the progress and application of science with its publication.

Other selected journals from SCIRP are listed as below. Submit your manuscript to us via either submit@scirp.org or Online Submission Portal.
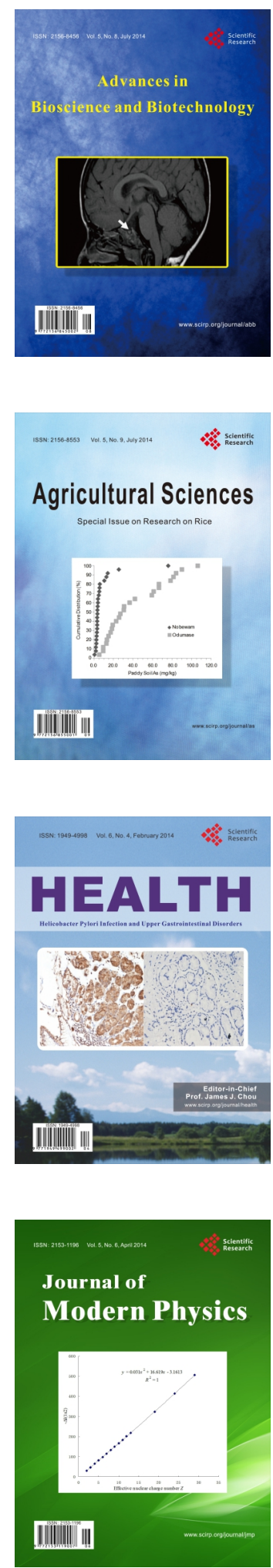
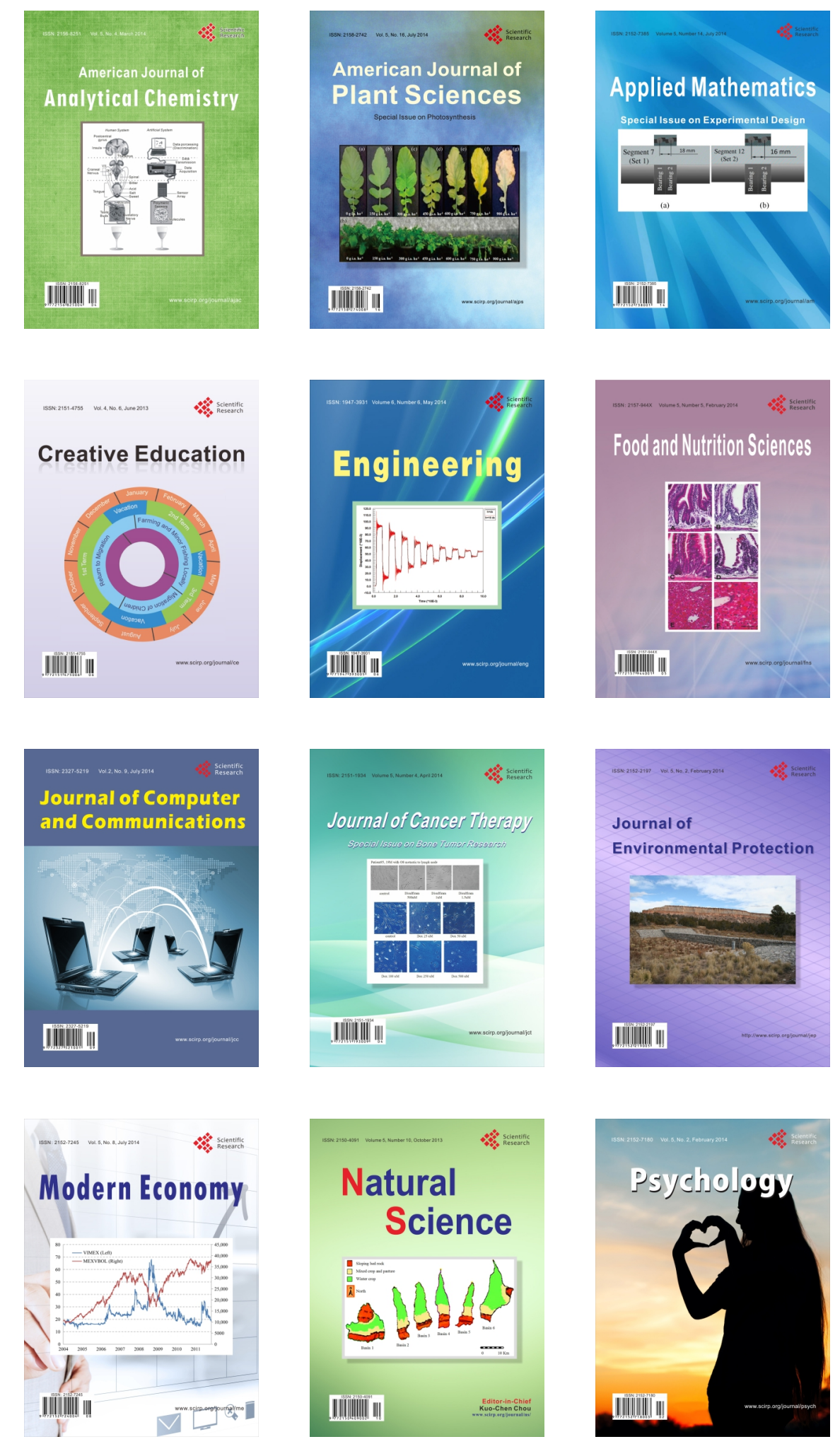